\title{
TELENURSING USING SKEDit TO EDUCATE PARENTS WITH THALASSEMIA CHILDREN
}

\section{Candra Andodo ${ }^{1}$, Fitri Haryanti², Widyandana ${ }^{3}$}

1. Student of Magister of Nursing, Faculty of Medicine, Public Health and Nursing, Universitas Gadjah Mada

2. Lecturer, Department of Medical Education, Faculty of Medicine, Public Health and Nursing Universitas Gadjah Mada

3. Lecturer of Nursing, Faculty of Medicine, Public Health and Nursing Gadjah Universitas Mada

\begin{abstract}
Excess iron levels and low hemoglobin $(\mathrm{Hb})$ levels are one of the complications of Beta Thalassemia. The aim of the study was to identify the effect of the implementation of education using SKEDit application compared to using booklets on parental knowledge and medication adherence in pediatric patients with thalassemia. The study was quasi-experimental using pre-post test with control. The total sample was 61 respondents with purposive sampling. Instrument using a thalassemia questionnaire and 'Pill Count'. The analyzed using the Mann whitney and wilcoxon test. There was a significant difference in the level of knowledge in the pretest and posttest on the intervention group $(p=0.001)$ and the pretest and posttest in the control group $(p=0.001)$. There was a significant difference in the level of adherence of the pretest and posttest in the intervention group $(p=0.028)$. There was no significant difference in the level of adherence of the pretest and posttest in the control group $(p=0.214)$. There was no difference in the level of knowledge between the two groups $(p=0.994)$. There was no difference in the level of adherence between the two groups $(p=0.987)$. Providing education using the SKEDit application and also booklets both effectively increase the level of parental knowledge and medication adherence.
\end{abstract}

Key words: Thalassemia, iron chelation, telenursing, knowledge, adherence

\section{ABSTRAK}

Kelebihan zat besi dan kadar hemoglobin $(\mathrm{Hb})$ yang rendah pada thalassemia beta rentan terhadap komplikasi. Tujuan penelitian untuk mengidentifikasi pengaruh pemberian pendidikan menggunakan aplikasi SKEDit dibandingkan dengan buklet tentang pengetahuan orang tua dan kepatuhan untuk minum obat untuk pasien anak-anak dengan thalassemia. Penelitian ini adalah eksperimen semu, pretest dan posttest dengan kelompok kontrol. Total sampel 61 dengan teknik purposive sampling. Pengetahuan orang tua diukur dengan kuesioner pengetahuan orang tua tentang Thalassemia, tingkat kepatuhan diukur menggunakan metode tidak langsung dengan 'Pill Count'. Analisis menggunakan uji Mann whitney dan wilcoxon. Ada perbedaan yang signifikan dalam tingkat pengetahuan pretest dan posttest pada kelompok perlakuan $(p=0,001)$ dan pretest dan posttest pada kontrol $(p=0,001)$. Ada perbedaan yang signifikan dalam tingkat kepatuhan pretest dan posttest pada kelompok perlakuan $(p=0,028)$. Tidak ada perbedaan yang signifikan dalam tingkat kepatuhan pretest dan posttest pada kelompok kontrol $(p=0,214)$. Tidak ada perbedaan dalam tingkat pengetahuan antara kedua kelompok $(p=0,994)$. Tidak ada perbedaan dalam tingkat kepatuhan antara kedua kelompok $(p=0,987)$. Pendidikan menggunakan aplikasi SKEDit, dan booklet, keduanya efektif meningkatkan pengetahuan dan kepatuhan.

Kata Kunci : Talasemia, kelasi besi, telenursing, pengetahuan, kepatuhan 


\section{BACKGROUND}

Thalassemia is a single gene disorder with the most types and frequencies in the world (Higgs, 2013). In 2016, there were 7238 people with thalassemia major recorded and reported by the Thalassemia Foundation of Indonesia (Dahnil, Mardhiyah, \& Widianti, 2017). Clinically, beta thalassemia major is the most severe symptom and it requires periodic blood transfusions (Aydinok, 2014). Blood transfusions have the effect of increasing iron accumulation in the blood (Aydinok, 2014). Chelation therapy is able to reduce the cumulative effects of iron (Fortin, et al., 2018). The problem that occurs in thalassemia patients is the low $\mathrm{Hb}$ levels and the excess of iron (Aydinok, 2014).

An evaluation of thalassemia interventions needs to be conducted as based on the research by Qurbani, Reniarti, Chairulfatah (2017), which studied approximately 40 hemosiderotic thalassemia major patients aged between 6-14 years at the Thalassemia Clinic in Dr. Hasan Sadikin Hospital, Bandung and it showed that $73 \%$ had an average $\mathrm{Hb}$ level of less than $7,2 \mathrm{~g} / \mathrm{dl}$ and an average/median serum ferritin level of $3.687 \mathrm{ng} / \mathrm{ml}$ before transfusion. This condition i.e. the level of $\mathrm{HB}$ and serum ferritin not being in accordance with the target level required for therapy causes persons with thalassemia to be susceptible to complications (Aydinok, 2014).

Based on the preliminary study conducted on February 15, 2018 in Banyumas Hospital, on 17 pediatric patients, 15 of them had ferritin levels above $1500 \mathrm{ng} / \mathrm{ml}$ and some even reached $10,857 \mathrm{ng} / \mathrm{ml}$. The number of thalassemia sufferers in the study was 445 people, 269 were children below school age and 131 of them were of school age. 'School age' is an important period in the stage of growth and development, at this stage children begin to show their own characteristics and abilities in terms of self-care (Hahn, 2015). At school age, children are able to adapt to be able to maintain their health status and understand the condition of the illness they are suffering from (Bowden et al., 1998). Non-adherence to iron chelation in children is due to the bitter taste of the drug, the difficulty in swallowing the drugs, and the lack of reminders to take the medication (Andodo, 2019).

Adherence to iron chelation is influenced by external mediators including the type or characteristics of the therapy, the previous iron chelation consumption habits, socio-economic, clinic or medical support, and parental involvement (Badawy et al., 2017). Parental involvement in managing iron chelation adherence in pediatric patients is a complex relationship (Foe et al., 2017). Families who act as supervisors will be more efficient and effective at managing their child's medication compared to the very limited supervision conducted by medical staff or health volunteers (Badawy et al., 2017).

Parental knowledge of the disease's conditions, care, and social support affect the efforts of the children themselves to be involved in their own self-care (Gadsden, Ford \& Brainer, 2016). Self-care includes choosing activities of efficient energy, consuming low iron foods and taking the prescribed drugs (Badawy et al., 2017). Pratama, et al., (2013) showed an association between parents' knowledge and the child's adherence to medication. The strategy was carried out to increase the knowledge of parents and thalassemia patients in Banyumas Hospital through counseling or providing information from officers using lecture methods and booklet media. The lecture method and booklet media strategy were conducted once a month during blood control and transfusion. The method was considered to be ineffective considering the high level of iron chelation prescribed to the patient.

The development of the technological era makes information and learning resources available everywhere (Andodo,2019). Many technology updates and social networks are available that help people communicate from a distance. WhatsApp is a popular social media application in Indonesian society (Andodo, 2019). The existence of the WhatsApp group which is followed by patients, parents, nurses and YTI Banyumas administrators, can be used as a reminder 
to take medication, exchange information, and to create learning discussion forums to disseminate learning materials.

One of the advantages of using the mobile phone for health intervention media is that the trend is to carry cellphones everywhere (Andodo, 2019). This makes it easier for health workers to send information and support to patients or patients can access information and support to health workers independently (Wahyuni, Rahayujati, \& Hakimi , 2017). Telenursing is defined as a process of giving, managing and coordinating care and providing health services through information technology and telecommunications (Canadian Nurses Assosiation, 2005). Technology progresses rapidly (Badawy et al., 2017), thus the researchers wanted to know the effect of education through WhatsApp media using the SKEDit application on parental knowledge and adherence to taking medication for children with thalassemia. SKEDit is a free and easy-touse scheduling app that lets you schedule WhatsApp messages, SMS, posts, as well as send emails and set call reminders. This top-rated Android scheduling app acts like your personal virtual assistant.

Based on the description above, the researchers wanted to know the effect of education through WhatsApp media using the SKEDit application on parental knowledge and medication adherence in children with thalassemia. The researchers used the control group as a comparison to assess the effectiveness of the intervention. The control group in this study was given education through a booklet. The reason for choosing education through booklets as a comparison is from the aspect of equality in comparing the two educational media. WhatsApp and booklets are both interventions that use visual stimulation.

\section{METHODS}

This research used quasiexperimental, pre-test and post-test with control group design. The population in this study were parents of pediatric thalassemia patients who were transfused in the Integrated Thalassemia Service Unit of Banyumas Hospital. Ethical clearance number Ref: KE / FK / 0724 / EC / 2018 was declared as passed on July 19, 2018. The sampling technique used in this study was purposive sampling. The sample in this study consisted of two groups, namely the control group and the intervention group. The number of respondents in the intervention group was 31 respondents and in the control group was as many as 30 respondents. The data were then analyzed using the Mann whitney and Wilcoxon test.

Parental knowledge was measured using the Parental knowledge about Thalassemia questionnaire developed by Arneli et. al., (2005). The questionnaire about the knowledge level of thalassemia consists of 6 domains namely the definition of thalassemia, screening, therapy, signs and symptoms, causes or inheritance and complications of thalassemia. The questionnaire about parental knowledge of thalassemia consists of 33 questions, using the Guttman scale with "Yes", "No", and "Don't know" answers. For the interpretation of answers we used the Guttman scale, namely correct and incorrect. Results interpretation was based on the percentage of total correct answers from a score of $0-100$.

Patient's adherence to iron chelation therapy was measured using the indirect method of pill counting to calculate the amount of drug that reduced the rest of the drug received divided by the number of the drugs received. The interpretation of the results was based on the percentage of adherence with a score between 0-100. A higher adherence score reflects a better adherence to medication.

There were two types of education media used in this study, softcopy image media, which were implemented in the intervention group while in the control group the booklet in hardcopy form were used. The source of materials was taken from www.p2ptm.kemenkes.go.id educational media section and from the materials related to the results of discussions with health workers in the Banyumas hospital of Thalassemia Room, and Thalassemia Foundation of Indonesia. The content of educational media related to thalassemia 
knowledge consisted of understanding, types, opinions, screening, therapy, consideration, inheritance patterns, diet, and complications of thalassemia.

SKEDit is an application used to schedule WhatsApp messages using a smartphone. Researchers send WhatsApp messages in regular time using the SKEDit application and the respondents can respond to the message via WhatsApp media. The process of sending messages is done every day. Text messages contain reminders to take medication, motivation to take th $\mathrm{e}$ medication and pictures of thalassemia (softcopy) education media.

\section{Research Procedure :}

1. Intervention Group

1) The researchers conducted a pre-test by distributing questionnaires on respondents' characteristics, knowledge questionnaires and adherence level questionnaires. 2) The researchers then recorded the next transfusion schedule and drug collection schedule. 3) The researchers recorded the respondents' data and added the respondents' telephone contact number to the cell phone used in the study. 4) Researchers scheduled messages, arranged text and image messages using the SKEDit application, and ensured data packages. 5) Researchers sent reminder messages in the form of multimedia messages via WhatsApp with the help of the SKEDit application. Material delivery was done every day (every morning) for a month. 6)
Respondents were able to send messages via WhatsApp to the researchers. WhatsApp messages were responded to by the researchers according to the level of urgency i.e. whether they must be immediately responded to at that time or there needed further discussion with a nurse or doctor in the Thalassemia room. The researchers conducted a post-test when the return visit was scheduled. The schedule of visits for transfusion and taking drugs varied depending on the respondents.

\section{Control group}

The researchers conducted a pre-test by distributing questionnaires on respondents' characteristics, knowledge questionnaires and adherence level questionnaires. In the control group the researcher gave a booklet after the pretest. It contained understanding, signs and symptoms, management, complications, and selfintervention of thalassemia in hardcopy. The researchers conducted a post-test at the time of control and transfusion according to the schedule of the patients' visit.

\section{RESULTS}

1. Demographic characteristics

Characteristics of respondents included their age, sex, their supervisors for taking medication, parents' names, parents' age, parents' sex, number of children, parental education level, and parents' occupation. The characteristics of the research subjects in the intervention and control groups are described in Table 1.

Table 1. Characteristic Data of Respondents

\begin{tabular}{lccccc}
\hline Characteristics of respondents & \multicolumn{2}{l}{ Intervention } & \multicolumn{2}{c}{ Control } & \multirow{2}{*}{$\boldsymbol{p}$-value } \\
\cline { 1 - 4 } & $\mathbf{F}$ & $\%$ & $\mathbf{F}$ & $\%$ & \\
\cline { 1 - 4 } Age of child (year) & 7 & 22.6 & 2 & 6.7 & 0.142 \\
$\mathbf{7}$ & 7 & 22.6 & 2 & 6.7 & \\
8 & 2 & 6,5 & 6 & 20 & \\
9 & 3 & 9,7 & 6 & 20 & \\
10 & 3 & 9,7 & 3 & 10 & \\
11 & 6 & 19.4 & 6 & 20 & \\
12 & 3 & 9,7 & 5 & 16.7 & \\
$\quad$ Total & 31 & 100 & 30 & 100 & \\
Sex of Child & & & & & \\
$\quad$ Boy & 18 & 58.1 & 11 & 36.7 & 0.082 \\
$\quad$ Girl & 13 & 41.9 & 19 & 63.3 & \\
$\quad$ Total & 31 & 100 & 30 & 100 & \\
Iron chelation & & & & & \\
$\quad$ Ferriprox tablet & 22 & 71.0 & 22 & 73.3 & 0.740 \\
\hline
\end{tabular}




\begin{tabular}{|c|c|c|c|c|c|}
\hline \multirow[t]{2}{*}{ Characteristics of respondents } & \multicolumn{2}{|c|}{ Intervention } & \multicolumn{2}{|c|}{ Control } & \multirow{2}{*}{$p$-value } \\
\hline & $\mathbf{F}$ & $\%$ & $\mathbf{F}$ & $\%$ & \\
\hline Ferriprox syrup & 8 & 25.8 & 6 & 20.0 & \\
\hline Exjade & 1 & 3.2 & 2 & 6.7 & \\
\hline Total & 31 & 100 & 30 & 100 & \\
\hline \multicolumn{6}{|l|}{ Supervisors of taking medication } \\
\hline Father & 4 & 12.9 & 7 & 23.3 & 0.176 \\
\hline Mother & 27 & 87.1 & 23 & 76.7 & \\
\hline Total & 31 & 100 & 30 & 100 & \\
\hline \multicolumn{6}{|l|}{ Age of parents (year) } \\
\hline $16-25$ & 1 & 3.2 & 0 & 0 & 0,327 \\
\hline $26-35$ & 12 & 38.7 & 7 & 23.3 & \\
\hline $36-45$ & 15 & 48.4 & 15 & 50 & \\
\hline $46-55$ & 3 & 9.7 & 6 & 20 & \\
\hline $56-65$ & 0 & 0 & 2 & 6.7 & \\
\hline Total & 31 & 100 & 30 & 100 & \\
\hline \multicolumn{6}{|l|}{ Parent's educational level } \\
\hline a. Primary school & 4 & 12.9 & 10 & 33.3 & 0,021 \\
\hline b. Middle school & 10 & 32.3 & 11 & 36.7 & \\
\hline c. High school & 11 & 35.5 & 9 & 30.0 & \\
\hline d. Higher education & 6 & 19.4 & 0 & 0 & \\
\hline Total & 31 & 100 & 30 & 100 & \\
\hline \multicolumn{6}{|l|}{ Parents' occupation } \\
\hline a. working & 10 & 32,2 & 8 & 26.7 & 0.782 \\
\hline b. not working & 21 & 67,7 & 22 & 73.3 & \\
\hline Total & 31 & 100 & 30 & 100 & \\
\hline \multicolumn{6}{|l|}{ Number of children } \\
\hline 1 & 10 & 32.3 & 8 & 22.7 & 0,340 \\
\hline 2 & 12 & 38.7 & 9 & 30.0 & \\
\hline 3 & 9 & 29.0 & 9 & 30.0 & \\
\hline 4 & 0 & 0 & 3 & 10 & \\
\hline 5 & 0 & 0 & 1 & 3.3 & \\
\hline Total & 31 & 100 & 30 & 100 & \\
\hline
\end{tabular}

Based on Table 1. It can be seen that most of the characteristics of respondents in the intervention group and the control group were homogeneous. The results of the statistical analysis showed a value of $p>0.05$ so it can be concluded that there were no differences in the respondents' characteristics between the intervention and control groups. The characteristics of educational level of parents showed that there were significant differences in the two groups, after a comparative test there was no difference with the dependent variable (level of knowledge and adherence).

2. The Difference in the mean level of knowledge and iron chelation therapy adherence at the pretest and posttest of respondents in the Thalassemia Room of Banyumas General Hospital $(n ; 63)$.

Table 2. The mean difference in knowledge scores and iron chelation adherence at the pretest and posttest in the Thalassemia Room at Banyumas General Hospital $(n=63)$

\begin{tabular}{|c|c|c|c|c|}
\hline Variable & $\begin{array}{c}\text { Pretest } \\
\text { Mean (min-max) }\end{array}$ & $\begin{array}{c}\text { Posttest } \\
\text { Mean (min-max) } \\
\end{array}$ & $\Delta$ mean & $p$ value ${ }^{\star}$ \\
\hline \multicolumn{5}{|c|}{ Knowledge } \\
\hline Intervention & $69,87(32-97)$ & $81.16(41-97)$ & 11,29 & 0.001 \\
\hline Control & $64.53(32-88)$ & $75.50(38-94)$ & 10.97 & 0.001 \\
\hline \multicolumn{5}{|c|}{ Adherence of iron chelation } \\
\hline Intervention & $87.03(34-100)$ & $90.29(33-100)$ & 3,26 & 0.028 \\
\hline Control & $83.81(47-100)$ & $87.08(33-100)$ & 3,27 & 0.214 \\
\hline
\end{tabular}

The results of the normality level test (pretest-posttest) in both groups showed that data was not normally distributed. Based on the results of the 
Wilcoxon test, the level of knowledge in the intervention group were obtained sig: $0.001(p<0,05)$. This shows that there is a significant difference in the level of knowledge between the pretest - posttest of the intervention group. The results of the Wilcoxon test on the level of knowledge in the control group were obtained sig: $0.001 \quad(p<0.05)$. This shows that there is a significant difference in the level of knowledge between the pretest and posttest of the control group.

Moreover, the results of the Wilcoxon test on the level of adherence in the intervention group obtained a sig value
: $0.028(p<0.05)$. This shows that there is a significant difference in the level of adherence between the pretest - posttest of the intervention group. Furthermore, the results of the Wilcoxon test on level of adherence in the control group obtained a sig value : $0.214(p>0.05)$. This shows there is no significant difference in the level of adherence between the pretest posttest control group.

3. The difference in the level of knowledge and level of adherence between the intervention and control groups.

Table 3. Difference in level of knowledge and level of adherence between the intervention and control groups

\begin{tabular}{lccccc}
\hline & & $\Delta$ mean & Mean Rank & Sum of Rank & $P$ value \\
\hline $\begin{array}{l}\text { Knowladge difference } \\
\quad \text { Intervention }\end{array}$ & 31 & 11.29 & 30,98 & 960.50 & 0.994 \\
$\quad$ Control & 30 & 10.97 & 31.02 & 930.50 & \\
$\begin{array}{l}\text { Adherence Difference } \\
\quad \text { Intervention }\end{array}$ & 31 & 3.26 & 31.03 & 962.00 & 0.987 \\
$\quad$ Control & 30 & 3.27 & 30.97 & 929.00 & \\
\hline
\end{tabular}

The table above shows that there is no difference in the level of knowledge between the intervention group and the control group with a $p$ value : $0.994(p>$ 0.05). Based on the table, the level of adherence between the intervention group and the control group indicates the similar score with a value of $p: 0.987$ ( $p>0.05)$.

\section{DISCUSSION}

1. The effect of education using WhatsApp through the SKEDit application and a booklet on the level of knowledge of parents of pediatric patients with thalassemia.

Analysis of mean differences was carried out to determine differences in the average knowledge before and after the intervention period both in the intervention and control groups. The results showed that there was a significant difference in the level of knowledge between the pretest-posttest intervention group with the value of sig: $0.001 \quad(p<0.05)$. These results indicate that the implementation of education using the SKEDit application through WhatsApp given to intervention groups can increase the knowledge of parents.
The results of this study are supported by Barhoumi's (2015) research that the learning process integrated with WhatsApp makes learning activities more effective. The use of WhatsApp technology is quite easy, it allows us to get the messages quickly, and it facilitates the rapid exchange of ideas.

All respondents in the active intervention group used WhatsApp to communicate in everyday life so that effective learning material could be read at any time and was practical. From the observations during the education process through WhatsApp, it was found that parents enthusiastically asked and commented. This shows that respondents are enthusiastic about education through WhatsApp media.

The increase in the score of thalassemia knowledge from the application of education and information through WhatsApp media can be explained by the precede-proceeded theory proposed by Green \& Kreuter (2005). Based on this theory, knowledge is a predisposing factor (tendency) that can be influenced by health education and appropriate health intervention media. 
In this study, the respondents in the intervention group received a message every day. According to Hahn \& Truman (2015) who revealed that the change from short-term memory to long-term memory requires memory consolidation. Memory consolidation requires a minimum of $5-10$ minutes and up to 1 hour for strong consolidation (Green \& Kreuter, 2005). In education through WhatsApp, short-term memory activation is carried out through messages sent continuously. The activation of repetitive short-term memory can activate chemical, physical, and anatomical changes at the synapse that are responsible for long-term memory (Hahn \& Truman, 2015). Thus, it allows respondents to improve their memory of information previously obtained. This is shown by the increase of parental knowledge about thalassemia.

The results of the Wilcoxon test on the level of knowledge in the control group were obtained sig: $0.001(p<0.05)$. This shows that there is a significant difference in the level of knowledge between the pretest - posttest control group. These results indicate that education using booklets in the control group can significantly increase knowledge. Educating is any effort carried out in order to influence other people, individuals, groups or communities so that they do what is expected by educators (Ningsih \& Yulianti, 2015).

The booklet in this study was printed media designed as a medium of education or health education related to thalassemia. As a form of educational media the booklet has advantages such as being able to be stored for a long time, as well as being an independent learning tool. Moreover the users can view their contents when they get home, there is a broader target reach and the booklet is compatible with other media, while the disadvantages of the booklet are that there is a need for a good reading ability and, if the booklet quality is poor, people will be reluctant to read or save it. The success of the booklet also relies on the willingness of target readers and the material is usually mass produced designed for general goals (Silalalhi, Lismidiati \& Hakimi, 2018). However, in spite of the disadvantages, using print media as a medium to provide health education can significantly increase people's knowledge.

The results of this study indicated that there was no difference in the level of knowledge between the intervention group and the control group with a $p$ value: 0.994 ( $p>0.05)$. These results show that education using booklets and education through WhatsApp media sent using the SKEDit application is equally effective in increasing the knowledge level. In this study the education through WhatsApp and booklets both used visual media so that the increase in the knowledge level is equally high. In accordance with the cone of Dale's experience, it describes that people generally remember $10 \%$ of what they read and $30 \%$ of what they see in the form of images (Anderson, 2016). Both the booklet and WhatsApp groups generally memorized about $30 \%$ of what they saw from the visual education provided. Education in this study was also provided using the same material so that it enabled respondents to remember the same thing.

Besides, education through WhatsApp media and booklets is seen as interesting and is easy to understand for the respondents. Providing education accompanied by interesting and easy to understand material will increase students' passion for learning and therefore it increases the interest of students to read material (Hahn \& Truman, 2015). Both media can also be read at any time. A small booklet designed with attractive images allows the mother to read it whenever she wants. Whereas WhatsApp integrated within a smartphone allows mothers to access the link at anytime. The use of WhatsApp as an educational tool overcomes the limitations of distance, time and space which is as an obstacle for educators when delivering their education (Andodo, 2019).

A similar result in the knowledge level can also be affected by educational media content in the intervention and control groups, which are the same. Both relate to thalassemia knowledge which consists of understanding, types, symptoms, screening, prevention, therapy, inheritance patterns, diet, and complications of thalassemia. Every 
respondent in each group received health education from health workers when their children were diagnosed with thalassemia.

2. The effect of education using WhatsApp through the SKEDit application and booklet on the adherence to iron chelation medication in children with thalassemia.

In the intervention group, the mean of adherence before the intervention period was 87.03 and in the control group was 83.81. Based on the results of the pretest homogeneity test from the level of adherence, the sig value reached: 0.413 ( $p>0.05)$. This shows that there is no significant difference in the pretest score of the level of adherence between the intervention group and the control group, so it can be concluded that the two groups have an equivalent level of initial adherence.

The results of this study also indicate that there is a significant difference in the level of adherence between the pretest-posttest intervention group with a sig value: 0.028 ( $p<0.05)$. This result shows that sending scheduled education and medication reminder messages through the SKEDit application via WhatsApp (given to the intervention group) can improve medication adherence.

Based on the precede-proceeded theory proposed by Green \& Kreuter (2005), scheduled education and reminder messages for taking medication act as reinforcing factors, which are factors that follow behaviors that provide stimuli or continuous stimuli so that behavior is repeated or sustained. The behavior in this study is iron chelation adherence.

The research of Osborne, et al., (2007) emphasized that optimizing iron chelation therapy in patients with major beta thalassemia is highly necessary. Iron chelation therapy in children with thalassemia aims to reduce excess iron in the body (Safitri, Ernawaty, Karim, 2015). Iron chelation therapy is effective in lowering levels of iron and increasing the life expectancy of patients with thalassemia when the patients adhere to taking the medication (Aydinok, 2014).
Characteristics of school-age children include many activities outside the home for around 4-5 hours. As the physical activity of children increases such as going and coming back home and playing with friends, this makes the role of parents very important when reminding their children to take medicine. Children sometimes do not take iron chelators during the day because they enjoy playing and forget to take it.

The results of the Wilcoxon test in the level of adherence in the control group obtained a sig: 0.214 ( $p>0.05)$. This shows there is no significant difference in the level of adherence between the pretest - posttest score in the control group. Patients with thalassemia in Banyumas Hospital at the time of blood transfusion receive motivation and reminders to take medicine directly by health workers at least once a month.

Chelation orally, i.e. deferiprone (ferriprox) is more effective than parenteral chelation, i.e. desferrioxamine in removing iron in the myocardial and this is supported by Hawsawi et al. (2010) who showed that the oral administration of deferiprone (ferriprox) resulted in a significant increase in myocardial iron secretion. The study also explained that the subcutaneous administration of Desferioxamine caused problems socially and psychologically in the lives of children and their families.

The results of this study also showed that there was no difference in the level of adherence between the intervention group and the control group with a $p$ value: $0.987(p>0.05)$. This might have been caused by the motivation and reminders to take medicine given directly by health workers to all thalassemia sufferers in Banyumas Hospital during the blood transfusion visits.

The similar score in the level of adherence between intervention and control groups can be explained due to the same educational content being received by all the respondents. Researchers found it difficult to control the educational media delivery interventions and medication reminders sent through WhatsApp media to the intervention group because they were then distributed to the control group, 
although it was explained clearly and written on the explanation sheet that it was prohibited to send or spread messages during the research process. This resulted in the control group being exposed to the same intervention of sending messages using WhatsApp as the intervention group. Factors that influence the adherence of taking medication according to Jin et al. (2008) include: patient-centered factors, therapeutic related factors, health service system factors, disease factors, and social and economic factors. Knowledge of families, especially parents, is an external factor that influences adherence to iron chelation (Badawy et al., 2017). Families play a psychosocial role by helping to solve problems, promoting good communication and helping children to deal with physical and psychological changes (Thanarattanakorn et al., 2003). Family support for thalassemia patients includes providing foods that contain low iron, delivering them to hospitals for transfusion and to take drugs, and helping them in their daily activities (Indanah, 2010). The ability of parents to convey important information and supervise the taking of medication is a supporting factor for adherence to iron chelation (Badawy et al., 2017).

The weakness of this study is that the researchers did not examine the length of time the patients had been consuming iron chelation drugs. Lengthy consumption of drugs, according to several theories, influences medication adherence.

\section{CONCLUSION AND}

\section{RECOMMENDATION}

1. Providing educational media, i.e. using the SKEDit application WhatsApp and booklets, has an effect on the knowledge level of parents of children with thalassemia. Providing educational media using the SKEDit application and booklets has an effect on children with thalassemia's level of adherence to iron chelation medication.

2. Providing education using WhatsApp through the SKEDit application has an effect on the adherence to iron chelation medication and there is no effect of education using booklets on the adherence to iron chelation medication in children with thalassemia.

Recommendations for future studies: An effort should be made to control participant drop out, which is by following up the respondents via making periodic appointments or contacting respondents (by phone call or SMS) a day before the scheduled transfusion and medication appointment.

\section{ACKNOWLEDGMENT}

We would like to thank Directorate of Higher Education, Ministry of Research and Technology, Indonesia for research funding for this study.

\section{REFERENCES}

Andodo, C., (2019). Pemberdayaan Telenursing Menggunakan Aplikasi Skedit Untuk Edukasi Orang Tua Pasien Anak Dengan Talasemia. Tesis. Universitas Gadjah Mada.

Anderson, H. M., (2016). Dale's Cone of Experience. Diakses dari www.queensu.ca/teachingandlearnin $\mathrm{g} /$ modules/active/documents/Dales Cones_of_Experience_summary.pdf . Online $1 \overline{4}$ November 2018.

Armeli, C., Robbins, S.J., \& Eunpu, D.L. (2005). Comparing Knowledge of $\beta$-Thalassemia in Samples of Italians, Italian-Americans, and Non-ItalianAmericans. Journal of Genetic Counseling, 14, 365-376.

Aydinok Y, Kattamis A, Viprakasit V. Current approach to iron chelation in children. British Journal of Haematology 2014;165(6):745-55.

Badawy, S. M., Morrone, K., Thompson, A., \& Palermo, T. M. (2017). Computer and mobile technology interventions to promote medication adherence and disease management in people with thalassemia. The Cochrane database of systematic reviews, 2017(12), CD012900. doi:10.1002/14651858.CD012900 
Barhoumi, C. (2015). The effectiveness of WhatsApp mobile learning activities guided by activity theory on student's knowledge management. Contemporary Educational Technology, 6(3), 221238

Bowden, V. R., Dickey, S. B \& Green, C. S. (1998). Children and Their Family; The Continuum of Care, Vol.1. WB. Philadelphia: Saunder Company

Canadian Nurses Association. (2005). Nurse One, The Canadian Nurses Portal Ottawa.

Dahnil, F., Mardiyah, A., \& Widianti, A. (2017). Kajian Kebutuhan Supportive Care Pada Orang Tua Anak Penderita Talasemia. NurseLine Journal. Vol. 2 No. 1 Mei 2017 pISSN 2540-7937 e-ISSN 2541-464X

Foe, M., Treadwell, M., J., Yamashita, R., Lal, A. (2017). Factors Related to Iron Chelation Therapy Adherence in Young Adults with Thalassemia: A Framework from the Patient Perspective. Program: Oral and Poster Abstracts. Session: 901. Health Services Research-NonMalignant Conditions: Poster I

Fortin, P. M., Fisher, S. A., Madgwick, K. V., Trivella, M., Hopewell, S., Doree, C., \& Estcourt, L. J. (2018). Interventions for improving adherence to iron chelation therapy in people with sickle cell disease or thalassaemia. The Cochrane database of systematic reviews, 5(5), CD012349. doi:10.1002/ 14651858.CD012349.pub2

Gadsden, V. L., Ford, M., \& Breiner, H. (EDS.. (2016). Parenting Matters: Supporting Parents of Children Ages 0-8. In National Academic Press. https://doi.org/10.18574/nyu/978081 4729151.003 .0010

Hahn, R. A., \& Truman, B.I., (2015). Education Improves Public Health and Promotes Health Equity. Int $\mathrm{J}$ Health Serv. 2015; 45(4):657-658.
Hawsawi, Z.M., Saifary, M.H., Tarawah, A.M., Zolaly, M.A., \& Hegaily, A.R. S. (2010). Experience with combination therapy of deferiprone and desferrioxamine in beta thalassemia major patients with iron overload at maternity and children hospital Al Madinah Al Munawarah Saudi Arabia. Journal of Taibah University Medical Sciences, 5 (1), 27-35.

Higgs D. R. (2013). The molecular basis of a-thalassemia. Cold Spring Harbor perspectives in medicine, 3(1), a011718. doi:10.1101/cshperspect.a 011718

Indanah; Yeti, K., \& Sabri, L. (2013). Dukungan Sosial Meningkatkan Selfcare Behaviour Anak. Jurnal Keperawatan Anak, Vol.1 No. 2:113119.

Jin, J., Sklar, G. E. Oh, V \& Li, S., (2008). Factors affecting therapeutic compliance: A review from the patient's perspective. Therapeutics and Clinical Risk Management, 4(1), pp.269-286.

Ningsih, E.D., \& Yulianti, T.S., (2015). Pengaruh Pemberian Pendidikan Kesehatan Tentang Bahaya Minuman Keras terhadap Sikap Remaja tentang Bahaya Minuman Keras Di Desa Pawisman Gedangan, Karanganyar. Jurnal Keperawatan GSH. Vol 4, No.2.

Osborne, R.H., Lourenco, R.D., Dalton, A.R., Houltram, J., Dowton, D., Joshua, D., Lindeman, R., \& Ho, P. (2007). Quality of life related to oral versus subcutaneous iron chelation: a time trade-off study. Value in health: the journal of the International Society for Pharmacoeconomics and Outcomes Research, 10 6, 451-6.

Pratama, A. N, W., Aliong, A. P. R., Sufianti, N., \& Rachmawati, E. (2018). Hubungan antara Tingkat Pengetahuan Pasien dan Pengawas 
Jurnal Keperawatan Soedirman 14 (3) 2019 : 174 - 184

Menelan Obat (PMO) dengan Kepatuhan Pasien Tuberkulosis di Puskesmas Kabupaten Jember $e$ Jurnal Pustaka Kesehatan, vol.6 (no.2),

Qurbani, S., N., Reniarti, L., Chairulfatah, A., (2017). Serum Ferritin, Serum Nitric Oxide, And Cognitive Function In Pediatric Thalassemia Major. Paediatrica Indonesiana.

Safitri, R., Ernawaty, J., Karim, D., (2015). Hubungan Kepatuhan Tranfusi Dan Konsumsi Kelasi Besi Terhadap Pertumbuhan Anak Dengan Thalasemia. Jurnal Online Mahasiswa (JOM). Vol 2 No 2, Oktober 2015.

Silalahi, V., Lismidiati, W., \& Hakimi, M., (2018). Efektivitas Audiovisual dan
Booklet sebagai Media Edukasi untuk Meningkatkan Perilaku Skrining IVA. JURNAL MKMI, Vol. 14 No. 3,

Thanarattanakorn, P., Louthrenoo, Orawan, Sittipreechacharn, Somjai, Sanguansermsri, Torpong. (2003). Family Functioning in Children with Thalassemia. Clinical Pediatrics; Jan/Feb 2003; 42, 1.

Wahyuni, Z., Rahayujati, B. T., \& Hakimi,. M. (2017). Pengaruh layanan pesan singkat terhadap pengetahuan dan intensi menyusui di kabupaten Purbalingga, Jawa Tengah. BKM Journal of Community Medicine and Public Health. Volume 33 Nomor 5.pp 261-266. 